\title{
DISTRIBUTION PATTERN OF TWO FISH SPECIES IN A COASTAL STREAM IN SOUTHEAST BRAZIL
}

\author{
MAZZONI, R. ${ }^{1}$ and IGLESIAS-RIOS, R. ${ }^{2}$ \\ ${ }^{1}$ Universidade do Estado do Rio de Janeiro, Instituto de Biologia Roberto Alcântara Gomes/Ecologia, \\ Rua São Francisco Xavier, 524, Maracanã, CEP 20550-013, Rio de Janeiro, RJ, Brazil \\ ${ }^{2}$ Universidade Federal do Rio de Janeiro, Instituto de Biologia, Departamento de Ecologia, \\ C.P. 68020 , Rio de Janeiro, RJ, Brazil \\ Correspondence to: Rosana Mazzoni, Universidade do Estado do Rio de Janeiro, Instituto de Biologia Roberto \\ Alcântara Gomes/Ecologia, Rua São Francisco Xavier, 524, Maracanã, \\ CEP 20550-013, Rio de Janeiro, RJ, Brazil
}

Received November 27, 2000 - Accepted February 2, 2001 - Distributed February 28, 2002

(With 3 figures)

\begin{abstract}
Longitudinal distribution of Mimagoniates microlepis and Hoplias malabaricus was analyzed in a coastal stream system in Southeast Brazil. Six sites were sampled by electrofishing in seven months, from July 94 to July 95. Densities of M. microlepis, and H. malabaricus and its prey (Poecilia vivipara, Deuterodon sp. and Astyanax janeiroensis) were estimated by the Zippin method; environmental variables of: (i) kind of substratum; (ii) percentage of pools, runs, riffles, instream vegetation, and canopy were registered for each site in each sampling month. The relative importance of each biotic and abiotic variable was tested through simple correlation analyses. We verified that $M$. microlepis occurrence correlates with canopy; $H$. malabaricus is correlated with instream vegetation, pools, clay substratum, and P. vivipara densities; and $P$. vivipara correlates with pools and clay substratum. Our results suggest that environmental variables, and food and shelter availability are the main factors in determining $M$. microlepis and $H$. malabaricus distribution.
\end{abstract}

Key words: stream fish distribution, East basin, Brazil.

\section{RESUMO}

\section{Padrão de distribuição de duas espécies de peixes em um riacho costeiro do Sudeste do Brasil}

A distribuição longitudinal de Mimagoniates microlepis e Hoplias malabaricus foi analisada em um riacho costeiro do Sudeste do Brasil. Durante sete meses, entre julho de 94 e julho de 95, seis localidades foram amostradas por pesca elétrica. As densidades de M. microlepis, H. malabaricus e suas presas (Poecilia vivipara, Deuterodon sp. e Astyanax janeiroensis) foram estimadas pelo método de Zippin. As variáveis ambientais de (i) tipo de substrato e (ii) percentual de poças, corredeiras, rápidos, vegetação aquática e cobertura vegetal foram registradas para cada localidade e mês de coleta. A importância relativa de cada variável, biótica e abiótica, foi testada por intermédio de análises de correlação simples. Verificamos que a ocorrência de $M$. microlepis está correlacionada à cobertura vegetal; $H$. malabaricus está correlacionada à vegetação aquática, poças, substrato argiloso e densidade de $P$. vivipara; e $P$. vivipara está correlacionada a poças e substrato argiloso. Nossos resultados sugerem que as variáveis ambientais e a disponibilidade de alimento e abrigo são os principais fatores determinantes na distribuição de M. microlepis e H. malabaricus.

Palavras-chave: distribuição de peixes de riacho, bacia do leste, Brasil. 


\section{INTRODUCTION}

Predicting parameters involved in organization of populations and communities continues to be a major challenge in animal ecology (Van Winkle et al., 1991; Matthews et al., 1994; Matthews, 1998). In trying to interpret mechanisms and processes underlying abundance and distribution of animal populations, divergent views have frequently developed throughout the history of ecology. Disagreement between defenders of biotic parameters, such as competition (e.g., Huntchinson, 1958; MacArthur, 1972), and abiotic ones, such as environmental settings (e.g., Andrewartha \& Birch, 1954; Connor \& Simberloff, 1979) has been common. This conflict continues, indicating the importance of physical versus biological processes in regulating the structure of stream-fish population and communities (Schlosser, 1987; Gelwick \& Matthews, 1993; Flecker, 1997).

Some researchers emphasize the importance of physical variables (Grossman et al., 1982) and others have documented the importance of biological interactions (Fraser \& Cerri, 1982; Power \& Matthews, 1983). Bayley \& Li (1992) suggest that environmental resources are the main factors in explaining fish species distribution and maintenance. Following this, the maintenance of populations reflects the interaction between environmental settings and adaptive characteristics of individuals of a species. Discussions go on, but present evidences corroborates both points of view.

In this paper we show the relative importance of environmental settings in determining densities and longitudinal distribution of Mimagoniates microlepis (Steindachner, 1876) and Hoplias malabaricus (Bloch, 1894) in the Ubatiba River. Behavioural and feeding habits of both species, provide the framework for these analyses.

\section{MATERIAL AND METHODS}

\section{Study area}

The Ubatiba River $\left(20^{\circ} \mathrm{S}\right.$ and $\left.42^{\circ} \mathrm{W}\right)$ together with its five tributaries composes a stream system in the Southeast of Brazil (Fig. 1). It flows for about $16 \mathrm{~km}$, on the east side of Serra do Mar, and discharges in the Maricá Lagoon located around 70 $\mathrm{km}$ from Rio de Janeiro City. Deforestation, as a consequence of cattle breeding, is the main lowland characteristic. Nonetheless, preserved areas of Atlantic Forest are still common on the slopes and tops of the surrounding rocky hills.

The Ubatiba River system is composed of streams with clear water and its hydric regime fluctuates according to rainfall $(\sim 1,500 \mathrm{~mm} /$ year $)$; more information about physicochemical characteristics of this system are presented elsewhere (Mazzoni, 1998; Mazzoni et al., 2000; Mazzoni \& Lobón-Cerviá, 2000).

\section{Sample procedure and data analysis}

Six sites were sampled bimonthly in the Ubatiba River system (Fig. 1) between July 94 and July 95 . These sites, between 70 and $100 \mathrm{~m}$ long, were selected to include all the variability of each particular stream. Width, depth, area, and water volume of each site, were determined at each sampling using bathymetric maps based on five-meter transects from the lowest sampled point downstream. Environmental settings were quantified by the percentage of silt, sand, pebble, gravel, and cobble; the sequence of pool, riffle, and runs was determined at each site. The relative importance of riparian and instream vegetation was considered as a percentage of the sampled area $\left(\mathrm{m}^{2}, \%\right)$ according to bathymetric maps (Table 1).

Fish numbers for each sampling site and date were determined by electrofishing techniques (220 V, 2.5 Amp, AC; see Mazzoni et al., 2000) through the three-removal method (Zippin, 1958), and transformed into fish density values for each sampled area. All collected fish were identified, measured (standard length, $\mathrm{SL}=\mathrm{mm}$ ), and released back into the water at a midpoint of the sampling site. All analyses were done according to mean fish densities at each site during the seven sampling periods.

To establish whether environmental settings determine density and distribution of $M$. microlepis and $H$. malabaricus, we used simple correlation analyses between their local mean densities and environmental settings; simple correlation analyses between mean densities of $H$. malabaricus and their prey (i.e., Poecilia vivipara Schneider, 1801, Astyanax janeiroensis Eigenmann, 1890 and Deuterodon sp.) were also done. 

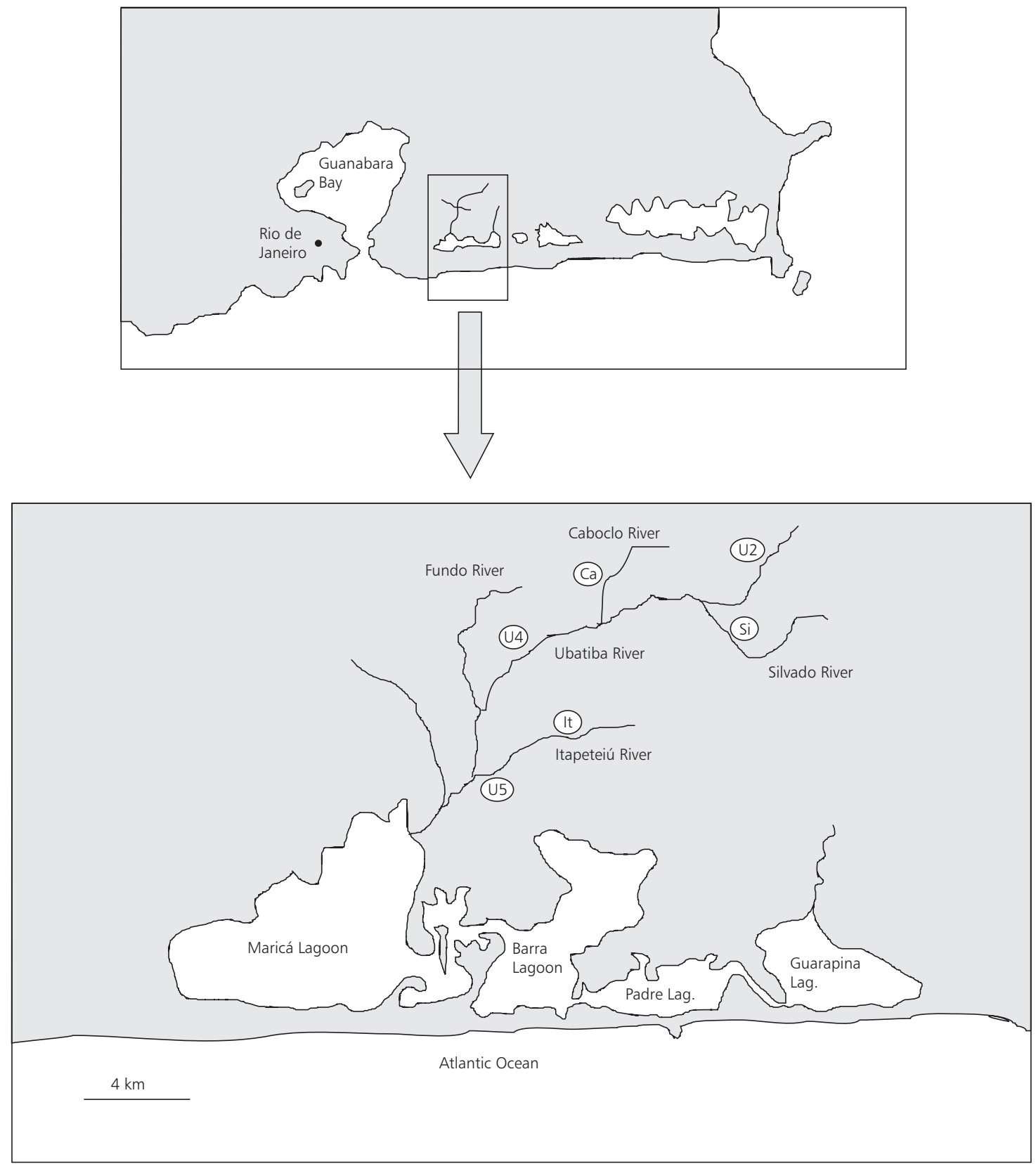

Fig. 1 - Geographical location of the Ubatiba River system showing the six sampling sites. 
TABLE 1

Percentage of environmental settings registered at each sampling site on the Ubatiba, Maricá, RJ. Si - Silvado, Ca - Caboclo, It -Itapeteiú, U2, U4 and U5 - Ubatiba River.

\begin{tabular}{|c|c|c|c|c|c|c|c|c|c|c|}
\hline \multirow{2}{*}{ Sites } & \multicolumn{2}{|c|}{ Hydric system } & \multicolumn{6}{|c|}{ Substratum } & \multirow{2}{*}{ Canopy } & \multirow{2}{*}{$\begin{array}{c}\text { Instream } \\
\text { vegetation }\end{array}$} \\
\hline & Pool & Riffle & Run & Silt & Sand & Gravel & Boulder & Rocks & & \\
\hline $\mathrm{Si}$ & 5 & 35 & 60 & 5 & 15 & 65 & 0 & 10 & 80 & 2 \\
\hline $\mathrm{Ca}$ & 10 & 0 & 90 & 5 & 10 & 80 & 0 & 0 & 0 & 75 \\
\hline It & 5 & 90 & 5 & 0 & 40 & 50 & 10 & 0 & 90 & 5 \\
\hline $\mathrm{U} 2$ & 16 & 60 & 24 & 15 & 10 & 5 & 70 & 0 & 0 & 90 \\
\hline $\mathrm{U} 4$ & 12 & 80 & 0 & 10 & 15 & 65 & 0 & 0 & 45 & 5 \\
\hline U5 & 14 & 73 & 13 & 15 & 50 & 20 & 15 & 0 & 7 & 80 \\
\hline
\end{tabular}

\section{RESULTS}

Descriptions of Ubatiba sites (Table 1) according to environmental settings show all presenting a combination of pools, runs, riffles, and variable substratum with no obvious longitudinal gradient but rather a mosaic of patches along the river; the negative correlation $(\mathrm{p}<0.01)$ between canopy and instream vegetation is noteworthy.

The highest percentages of instream vegetation were registered at $\mathrm{Ca}, \mathrm{U} 2$, and $\mathrm{U} 5$ while at $\mathrm{Si}$, It, and U4 canopy was the predominant vegetation.

Mean densities of $M$. microlepis, $H$. malabaricus, $P$. vivipara, A. janeiroensis, and Deuterodon sp. are presented in Table 2.

Sites U2 and Ca had no canopy and presented lower density of M. microlepis; in these cases, occur- rences were random and limited to 1 or 2 specimens. Even at site U5, with a poor canopy, the species was registered at the only shaded area (authors' personal observation). Sites Si, It, and U4 (28.4, 25.0 , and $12.7 \mathrm{ind} / \mathrm{ha}$, respectively) presented high M. microlepis densities and canopy (Fig. 2). Regression analyses between $M$. microlepis densities and canopy showed a positive correlation $\left(\mathrm{r}^{2}=\right.$ $0.87 ; \mathrm{p}<0.002$ ), the only significant one for $M$. microlepis.

Density of $H$. malabaricus correlated inversely with canopy $\left(\mathrm{r}^{2}=-0.70 ; \mathrm{p}<0.02\right)$ and positively with instream vegetation $\left(\mathrm{r}^{2}=0.84 ; \mathrm{p}<\right.$ $0.003)$ and pools $\left(r^{2}=0.82 ; \mathrm{p}<0.004\right)$. Therefore, sites with higher (Ca, U2, and U5) and lower ( $\mathrm{Si}$, It, and U4) instream vegetation are those with higher and lower densities of $H$. malabaricus, respectively (Fig. 3).

TABLE 2

Mean densities (ind/ha) of Hoplias malabaricus, Mimagoniates microlepis, and Poecilia vivipara at the six analyzed localities in the Ubatiba River system, between July 1994 and July 1995.

\begin{tabular}{|c|c|c|c|c|c|}
\hline Sites & M. microlepis & H. malabaricus & P. vivipara & A. janeiroensis & Deuterodon sp. \\
\hline $\mathrm{Si}$ & 28.4 & 2.7 & 10.2 & 31.9 & 66.1 \\
\hline $\mathrm{Ca}$ & 0.4 & 4.6 & 50.1 & 21.7 & 101.3 \\
\hline $\mathrm{It}$ & 25.0 & 2.9 & 26.1 & 40.9 & 313.0 \\
\hline $\mathrm{U} 2$ & 0.4 & 8.1 & 270.3 & 20.7 & 79.0 \\
\hline $\mathrm{U} 3$ & 0 & 8.3 & 279.3 & 21.2 & 64.1 \\
\hline $\mathrm{U} 4$ & 12.7 & 3.6 & 57.1 & 22.6 & 146.4 \\
\hline $\mathrm{U} 5$ & 13.0 & 8.1 & 161.6 & 34.7 & 308.7 \\
\hline
\end{tabular}




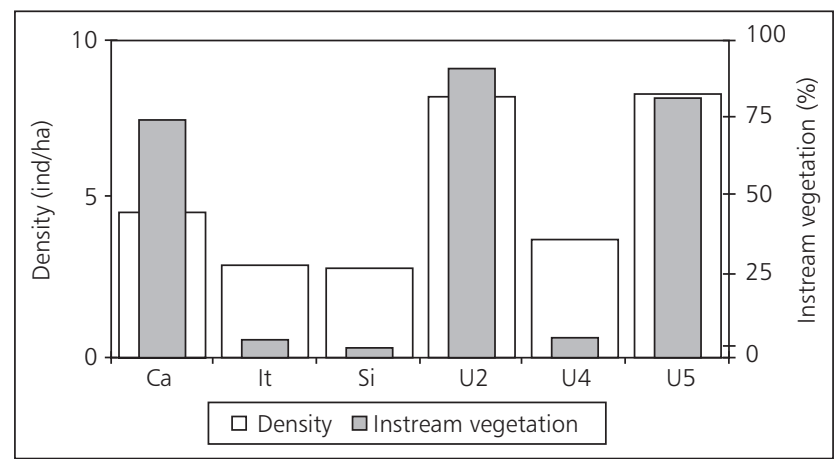

Fig. 2 - Mean densities (ind/ha) of Mimagoniates microlepis and percentage of canopy in the six study sites in the Ubatiba River system.

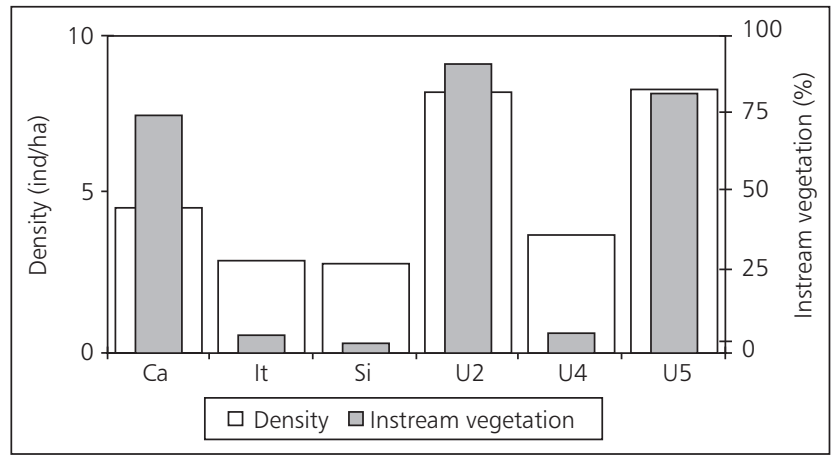

Fig. 3 - Mean densities (ind/ha) of Hoplias malabaricus and percentage of instream vegetation in the six study sites in the Ubatiba River system.

Correlation analysis between $H$. malabaricus densities and their potential prey, P. vivipara, Deuterodon sp., and A. janeiroensis, indicates that $H$. malabaricus densities increase as $P$. vivipara densities increase $\left(\mathrm{r}^{2}=0.88 ; \mathrm{p}<0.001\right) ; P$. vivipara densities increase at the same rate that pool $\left(\mathrm{r}^{2}=\right.$ $0.81 ; \mathrm{p}<0.006)$ and instream vegetation $\left(\mathrm{r}^{2}=0.70\right.$; $\mathrm{p}<0.02)$ do. No other significant correlation was detected among the analyzed cases.

\section{DISCUSSION}

Habitat use by fish species is related to morphological and physiological characters (Sale, 1969) including size, and form and position of fins in the first case (Wootton, 1990; Reilly \& Wainwright, 1994), and trophic (Ringler, 1983) and reproductive requirements (Balon, 1975) in the second.
M. microlepis shows diurnal behaviour, preferring shallow waters with medium to slow water velocity. Allochthonous insects are the main food of species that swim through the surface and/or midwater to eat (Sabino \& Castro, 1990). M. microlepis from the Ubatiba River feed mainly on terrestrial forms of Hymenoptera and Diptera (unpublished data), corroborating observations made by Sabino \& Castro (1990).

Our results point to positive correlation between canopy and M. microlepis densities; the first attempt to explain this was based on the premise that covered areas are richer in allochthonous food, mainly terrestrial insects, than are open ones. Input of allochthonous matter is considered the most important source of food supply in streams (Welcomme, 1985; Luiz et al., 1998), compensating low primary production, a situation 
intensified in sites with intense vegetative cover because of reduced sunlight incidence (Power, 1984; Sechnick et al., 1986). Nevertheless, data in the literature suggest that there are no quantifiable differences of allochthonous input between covered and opened areas (e.g., Angermeier \& Karr, 1983; Uieda \& Kikuchi, 1995). In view of these contrasting results, we suggest that preference for shaded sites may be explained by both input of allochthonous food and protection from terrestrial predators, mainly piscivorous birds. A changing and heterogeneous background of sun and shade, as a consequence of sun flecks or dappling due to partially open canopy, has been registered as a way of decreasing predation in streams (e.g., Helfman, 1981; Sechnick et al., 1986). Based on this rationale, the abundance of M. microlepis in shaded areas may be explained by its predation avoidance and trophic requirements.

Distribution of $H$. malabaricus can be approached in the same way. As a piscivorous species (Goulding, 1980; Lowe-McConnell, 1991), its main preys are A. janeiroensis, Deuterodon sp., and $P$. vivipara, the latter being most frequent in its diet (unpublished data). Our results indicate a strong correlation between $H$. malabaricus and instream vegetation and pool; the use of such an environment for forraging has been registered at a length for $H$. malabaricus (i.e., Uieda, 1984; Castro \& Casatti, 1997).

The positive correlations recorded between $P$. vivipara and $H$. malabaricus densities, as well as for $P$. vivipara densities, pools, and instream vegetation are in agreement with some data in the literature. Caramaschi (1979) noted that pools and instream vegetation were the main habitat used by Phalloceros caudimaculatus (Hensel, 1868) (Poeciliidae related to $P$. vivipara) and young $H$. malabaricus which in this case used Poeciliidae as its main food item. Such results associated with ours, suggest that occurrence and abundance of $H$. malabaricus may be strongly related to available food, in this case P. vivipara.

Feeding habits of Poeciliidae fishes have been extensively discussed and all agree on its characterization as herbivorous/algivorous (Costa, 1987; Teixeira, 1989; Sabino \& Castro, 1990; Aranha \& Caramaschi, 1999). Lentic habitats with poor or no shade facilitate filamentous and unicellular algae bank formation. Therefore, positive correlation between $P$. vivipara and pools in open sites suggests causal relationships with feeding habits; moreover, the size of these individuals facilitate high density in these sites.

We conclude that occurrence and abundance of fish species of the Ubatiba system can be related to their trophic (selecting microhabitats so as to maximize their ability to efficiently use local food supplies) and anti-predator requirements. $M$. microlepis, a water column species, had its highest density registered at shaded sites, which increase food availability (i.e., terrestrial insects) and allows predation evasion. H. malabaricus and P. vivipara densities were correlated with pools and instream vegetation; such environments are highly propitious for feeding Poeciliidae which, in turn, is the main food item for $H$. malabaricus of the Ubatiba River system.

Finally, we suggest that the environmental variables studied are the main factors in the fish community structure in the Ubatiba system; nevertheless, further analysis on the other fish species are needed to corroborate our proposition.

Acknowledgments - We thank the members of the Fish Ecology Laboratories of the Universidade do Estado do Rio de Janeiro and Universidade Federal do Rio de Janeiro for helping in the field work. Erica Pellegrini Caramaschi, Javier LobónCerviá, and the anonimous referee for valuable suggestions on the manuscript. We are grateful to Chiara Mazzoni for the English revision. This study was partially supported by CNPQ/ Projeto Integrado - proc. n. 521597/95-1.

\section{REFERENCES}

ANDREWARTHA, H. G. \& BIRCH, L. C., 1954, The distribution and abundance of animals. University of Chicago Press, Chicago, 782p.

ANGERMEIER, P. L. \& KARR, J. R., 1983, Fish communities along environmental gradients in a system of tropical streams. Environmental Biology of Fish, 9: 117-135.

ARANHA, J. M. \& CARAMASCHI, E. P., 1999, Estrutura populacional, aspectos da reprodução e alimentação dos Cyprinodontiformes (Osteichthyes) de um riacho do sudeste do Brasil. Revista Brasileira de Zoologia, 16: 637651

BALON, E. K., 1975, Reproductive guilds of fishes: a proposal and definition. Journal of the Fisheries Research Board of Canada, 32: 821-864.

BAYLEY, P. B. \& LI, H. W., 1992, Riverine fishes. In: P. Calow \& G. E. Petts (eds.), The river handbook: hydrological and ecological principles. Blackwell Scientific $\mathrm{Pu}-$ blications, vol. 1, pp. 251-281. 
CARAMASCHI, E. P., 1979, Reprodução e alimentação de Hoplias malabaricus (Bloch, 1794) na represa do rio Pardo (Botucatu, SP). Dissertação de Mestrado, Programa de Pós-graduação em Ecologia e Recursos Naturais, UFSCar, $144 \mathrm{p}$.

CASTRO, R. M. C. \& CASATTI, L., 1997, The fish fauna from a small forest stream of the Paraná river Basin, southeastern Brazil. Ichthyological Exploration of Freswaters, 7: $337-352$

CONNOR, E. F. \& SIMBERLOFF, D. S., 1979, The assembly of species communities: change or competition? Ecology, 60: 1132-1140.

COSTA, W. J. E. M., 1987, Feeding habits of a fish community in a Tropical coastal stream, rio Mato Grosso, Brasil. Studies on Neotropical Fauna and Environment, 22: 145 153.

FLECKER, A. S., 1997, Habitat modification by tropical fishes: environmental heterogeneity and the variability of interaction strength. Journal of North American Benthological Society, 16: 286-295.

FRASER, D. F. \& CERRI, R. D., 1982, Experimental evaluation of predator-prey relationships in a patchy environment: consequences for habitat use patterns in minnows. Ecology, 63: 307-313.

GELWICK, F. P. \& MATTHEWS, W. J., 1993, Artificial streams for studies of fish ecology. Journal of North American Benthological Society, 12: 343-347.

GOULDING, M., 1980, The fishes and the forest. University of California Press, Berkeley, 280p.

GROSSMAN, G. D., MOYLE, P. B. \& WHITAKER-Jr., J. O., 1982, Stochascity in structure and functional characteristics of na Indiana stream fish assemblage: a test of community theory. American Naturalist, 120: 423-454.

HELFMAN, G. S., 1981, The advantage to fishes of hovering in shade. Copeia, 1981: 392-400.

HUTCHINSON, G. E., 1958, Concluding remarks. Cold Spring Harbor Symposium of Quantitative Biology, 22: 415-427.

LOWE-McCONNELL, R. H., 1991, Ecological studies in tropical fish communities. Cambridge University Press, Cambridge, 382p.

LUIZ, E. A., AGOSTINHO, A. A., GOMES, L. C. \& HAHN, N. S., 1998, Ecologia trófica de peixes em dois riachos da bacia do rio Paraná. Revista Brasileira de Biologia, 58: 273-285.

MacARTHUR, R. H., 1972, Geographical ecology. Harper and Row, New York, 288p.

MATTHEWS, W. J., HARVEY, B. C. \& POWER, M. E., 1994 Spatial and temporal patterns in the fish assemblages of individual pools in a Midwestern stream (USA). Environmental Biology of Fish, 39: 381-397.

MATTHEWS, W. J., 1998, Patterns in Freshwater Fish Ecology. Chapman \& Hall, 756p.
MAZZONI, R., 1998, Estrutura das comunidades e produção de peixes de um sistema fluvial costeiro de Mata Atlântica, Rio de Janeiro. Tese de Doutorado, Universidade Federal de São Carlos, São Paulo, Brasil, 100p.

MAZZONI, R., FRENERICH-VERANI, N. \& CARAMASHI, E. P., 2000, Eletrofishing as a sampling technique for coastal stream fish populations in the Southeast of Brazil. Revista Brasileira de Biologia, 60: 205-216.

MAZZONI, R. \& LOBÓN-CERVIÁ, J., 2000, Longitudinal structure, density and production rates of a Neotropical stream fish assemblage: the river Ubatiba in the Serra do Mar (South-East Brazil). Ecography, 23: 588-602.

POWER, M. E., 1984, Habitat quality and the distribution of algae-grazing catfish in a panamanian stream. Journal of Animal Ecology, 53: 357-374.

POWER, M. E. \& MATTHEWS, W. J., 1983, Algae-grazing minnows (Campostoma anomalum), piscivorous bass (Micropterus spp.), and the distribution of attached algae in a small prairie-margin stream. Oecologia, 60:328332.

REILLY, S. M. \& WAINWRIGHT, P. C., 1994, Conclusion: ecological morphology and the power of integration. In: P. C. Wainwright \& S. M. Reilly (eds.), Ecological morphology: integrative organismal biology. The University of Chicago Press, pp. 339-354.

RINGLER, N. H., 1983, Variation in foraging tactics of fishes. In: D. L. G. Noakes, D. G. Lindquist, G. S. Helfman \& J. A. Ward (eds.), Predators and preys in fishes. Junk, The Hague, pp. 159-171.

SABINO, J. \& CASTRO, R. M. C., 1990, Alimentação, período de atividade e distribuição espacial dos peixes de um riacho da floresta Atlântica (sudeste do Brasil). Revista Brasileira de Biologia, 50: 23-36.

SALE, P. F., 1969, A suggested mechanism for habitat selection by juvenile manini Acanthurus triostegus sandvicensis Streets. Behaviour, 35: 27-44.

SCHLOSSER, I. J., 1989, A conceptual framework for fish communities in small warmwater streams. In: W. J. Matthews \& D. C. Heins (eds.), Community and evolutionary ecology of North American stream fishes. Oklahoma University Press, pp. 17-24.

SECHNICK, C. W., CARLINE, R. F., STEIN, R. A. \& RANKIN, E. T., 1986, Habitat selection by smallmouth bass in response to physical characteristics of a simulated stream. Transactions of American Fisheries Society, 115: 314-321.

TEIXEIRA, R. L., 1989, Aspectos da biologia de alguns peixes do arroio Bom Jardim, Triunfo, RS. Revista Brasileira de Biologia, 49: 183-192.

UIEDA, V. S., 1984, Ocorrência e distribuição dos peixes em um riacho de água doce. Revista Brasileira de Biologia, 44: 203-213. 
UIEDA, V. S. \& KIKUCHI, R. M., 1995, Entrada de material alóctone (detritos vegetais e invertebrados terrestres) num pequeno curso de água corrente na cuesta de Botucatu, São Paulo. Acta Limnologica Brasiliensia, VII: 105-114

Van WINKLE, W., ROSE, K. A., WINEMILLER, K. O., DeANGELIS, D. L., CHRISTENSEN, S. W., OTTO, R. G. \& SHUTER, B. J., 1991, Linking life history theory, environmental settings and individual-based modeling to compare responses of different fish species to environmental change. Transactions of the American Fisheries Society, 122: 459-466.
WELCOMME, R. L., 1985, Ontogenetic diet shifts and resource partitioning among piscivorous fishes in the Venezuelan llanos. Environmental Biology of Fish, 26: 177-199.

WOOTTON, R. J., 1990, Ecology of teleost fishes. Fish and Fisheries, Chapman \& Hall, 404p.

ZIPPIN, C., 1958, The removal method of population estimation. Journal of Wildlife Management, 22: 82-90. 